\title{
Functional response and particle size selection of Halteria cf. grandinella, a common freshwater oligotrichous ciliate
}

\author{
Klaus Jürgens ${ }^{1, *}$, Karel Šimek ${ }^{2,3}$ \\ ${ }^{1}$ Max Planck Institute of Limnology, PO Box 165, 24302 Plön, Germany \\ ${ }^{2}$ Hydrobiological Institute of the Academy of Sciences of the Czech Republic, and ${ }^{3}$ Faculty of Biological Sciences, \\ University of South Bohemia, Na sádkách 7, 37005 České Budějovice, Czech Republic
}

\begin{abstract}
In laboratory experiments, we studied the growth and feeding characteristics of Halteria cf. grandinella, a common and widespread oligotrichous ciliate in freshwater plankton. Particlesize-dependent feeding rates were measured with fluorescent latex micropheres $(0.22$ to $4.23 \mu \mathrm{m}$ diameter) and natural food organisms (bacteria, Synechococcus sp., Chlorella minutissima) in shortterm feeding experiments. $H$. cf. grandinella ingested all but the smallest $(0.22 \mu \mathrm{m})$ particles offered and demonstrated a concentration dependent type- 2 functional response. Maximum clearance rates were obtained with $2.76 \mu \mathrm{m}$ latex beads $\left(0.6 \mu \mathrm{h}^{-1}\right)$. Clearance rates declined for smaller and larger particle sizes but even with the suboptimal size classes, 0.47 and $1 \mu \mathrm{m}$, high maximal ingestion rates were measured (19 and 13 beads ciliate ${ }^{-1} \mathrm{~min}^{-1}$, respectively). The maximum clearance rates for bacteria and algae were close to those of similar sized latex beads, and no discrimination of particles based on properties other than size could be detected. The physiological state of the ciliates did not seem to have an impact on the relative pattern of the particle-size-dependent functional response curves, but the absolute feeding rates decreased nearly 10 -fold after prolonged starvation. The experiments demonstrated that this small filter-feeding ciliate is an omnivorous species which is able to efficiently exploit the planktonic prey size spectrum from 0.5 to $5 \mu \mathrm{m}$, covering heterotrophic and autotrophic pico- and nanoplankton in the diet.
\end{abstract}

KEY WORDS: Planktonic ciliate $\cdot$ Halteria $\cdot$ Oligotrichs $\cdot$ Growth $\cdot$ Feeding behaviour $\cdot$ Functional response $\cdot$ Prey selection

\section{INTRODUCTION}

Mainly due to studies within the last 10 to $15 \mathrm{yr}$, we now have a much better picture of the structure and function of freshwater, pelagic ciliate communities, as well as of the autecology of certain important taxa. Ciliates are now recognized as a major component of the microzooplankton and often constitute a significant portion of total zooplankton biomass and grazing impact (Pace \& Orcutt 1981, Taylor \& Heynen 1987, Beaver \& Crisman 1989, Weisse et al. 1990). It has become evident that planktonic ciliates in temperate

*E-mail: juergens@mpil-ploen.mpg.de lakes are generally dominated by small $(<30 \mu \mathrm{m})$ species, mainly of the orders Prostomatida and Oligotrichida (Müller 1989, Carrick \& Fahnenstiel 1990 Macek et al. 1996, Carrias et al. 1998). Particularly oligotrichs are present with mixotrophic and heterotrophic species across the whole trophic continuum (Laybourn-Parry 1994).

Whereas the grazing impact of ciliates on bacteria and phytoplankton has been repeatedly demonstrated in marine studies (Burkill et al. 1993, Verity et al. 1993), relatively few quantitative data are available from freshwater systems. Prostomatids, which are selective raptorial feeders, have been shown to temporarily exert a substantial grazing pressure on certain phytoplankton taxa (Weisse et al. 1990, Sommaruga \& Psen- 
ner 1993). In contrast, filter-feeding oligotrichs have been mainly found as significant grazers on auto- and heterotrophic picoplankton (Sanders et al. 1989, Šimek et al. 1995, 2000, Stabell 1996). The fact that naked oligotrichs have been identified as important bacterial feeders in marine (Sherr \& Sherr 1987) and limnetic (Šimek et al. 1995, 2000, in this issue) habitats challenged the original concept in which ciliates were regarded as unimportant bacterial consumers in pelagic habitats, due to their dependence on higher bacterial concentrations (Fenchel 1980a,b). This concept was developed, however, from studies on obligate bacterivorous species, whereas oligotrichous ciliates are probably omnivorous, as they feed on a wider prey size spectrum and do not depend on bacteria only. This has been supported by studies on cultured marine oligotrichs, mainly from the genus Strombidium (Jonsson 1986, Fenchel \& Jonsson 1988, Bernard \& Rassoulzadegan 1990).

Only few data on growth and feeding of small freshwater oligotrichous ciliates are available. The genera Halteria and Strobilidium (or Rimostrombidium) have been identified as numerically important taxa among the small oligotrichs in lake plankton (Müller 1989, Sanders et al. 1989, Šimek et al. 1995, Macek et al. 1996, Jürgens et al. 1999). Grazing measurements with fluorescently labelled picoplankton revealed exceptionally high feeding rates on bacteria and picoautotrophs by the ciliate Halteria, most probably H. grandinella (Sanders et al. 1989, Šimek et al. 1995, Stabell 1996), making this species temporarily the most important protistan bacterial consumer (Šimek et al. 2000). Grazing rates on phytoplankton except picocyanobacteria have not been measured for Halteria, but growth of cultured Halteria sp. on phytoplankton (Skogstad et al. 1987) and relatively high clearance rates on heterotrophic nanoflagellates (Cleven 1996, Jürgens et al. 1996) imply that it extends its prey size spectrum into the nanoplankton size range.

Some uncertainties remain with regard to the taxonomic status of different species of halteriids (Foissner 1994). Recently it has been reported that the genus Halteria sensu lato comprises several rather similar species (summarized in Foissner et al. 1999). H. grandinella Müller is likely the most important species, but H. bifurcata Tamar and Pelagohalteria cirrifera Kahl are quite similar, and can be differentiated from their somatic ciliature in silver impregnations (Foissner et al. 1999). These heterotrophic halteriids seem to be a widespread and common ciliate group from oligotrophic to eutrophic freshwater systems (Šimek et al. 2000). Another related species, which has been described in detail based on protargol impregnations (Foissner et al. 1999), is the mixotrophic Pelagohalteria viridis, which can be temporarily more abundant
(Jürgens et al. 1994, Macek et al. 1996, Carrias et al. 1998) and has been reported as an efficient picoplankton feeder as well (Šimek et al. 1996).

Halteria grandinella has also been studied with respect to behaviour (Tamar 1979) and vulnerability towards metazooplankton (Archbold \& Berger 1985, Gilbert 1994). Little information is available with regard to feeding rates and prey size spectrum. Only Fenchel (1986), in a comparison of various ciliates species, included data points from $H$. grandinella showing the uptake of particles $<1 \mu \mathrm{m}$.

The goal of the present study was to examine growth and feeding behaviour of Halteria cf. grandinella, to be able to make predictions about the prey spectrum and the potential grazing impact on planktonic bacteria and algae. For this we performed growth and shortterm ingestion experiments with a culture of $H$. cf. grandinella and various natural and artificial food particles. In conjunction with a second paper, which summarizes field data on abundance and grazing rates of Halteria spp. in different pelagic systems (Šimek et al. 2000), these data are used to suggest a revised concept of planktonic ciliate bacterivory, where the principal role is attributed to small omnivorous filter-feeding oligotrichous ciliates (Šimek et al. 2000).

\section{METHODS}

An oligotrichous ciliate, resembling descriptions of Halteria grandinella, was isolated from a mesotrophic lake in northern Germany (Schöhsee). However, because we did not examine the ciliature in silver impregnations, and due to the fact that 2 other very similar species, $H$. bifurcata and Pelagohalteria cirrifera, have been found in various European lakes (Foissner pers. comm.), we do not have a definitive species identification. Ciliates were maintained in multiclonal cultures on WC medium (Guillard \& Lorenzen 1972) and fed with either the cryptomonad Rhodomonas minuta (5-6 $\times 3-4 \mu \mathrm{m}$ in size) or, as another stock culture, with the green algae Chlamydomonas reinhardii (3-4 $\mu \mathrm{m}$ diameter). Both algae cultures were not axenic and accompanying bacteria $\left(2-5 \times 10^{6} \mathrm{ml}^{-1}\right)$ and detritus served as potential additional food sources for the ciliates.

Growth experiments. Stock cultures, as well as all experimental incubations, were located in a climate room $\left(16.5 \pm 0.5^{\circ} \mathrm{C}\right)$ under dim light. Growth experiments were performed in batch culture conditions. A numerical response was determined with Rhodomonas minuta only, whereas with Chlamydomonas reinhardii the growth rate was measured at a saturating food concentration. Ciliates were inoculated from cultures grown on $R$. minuta as food algae. Changes 
in the number of ciliates and prey were followed by sampling at regular time intervals for several days. Ciliates and algae were fixed in Lugol's solution and counted in a sedimenting chamber. Ciliate growth rates $\left(\mu, \mathrm{h}^{-1}\right)$ were calculated for the initial phase of exponential growth, covering 3 to 4 points per food concentration.

Digestion experiments. We measured ingestion and digestion rates of 3 potentially important food items for Halteria grandinella in situ, i.e., hetero- and autotrophic picoplankton, and small algae that have been frequently found in food vacuoles of natural populations of this ciliate in 2 reservoirs (for details see Šimek et al. 2000). These food items were: (1) a mixed assemblage of heat-killed, fluorescently labelled bacteria (FLB, mean cell volume $0.15 \mu^{3}$, grown in a carbonlimited chemostat and prepared according to Sherr et al. 1987); (2) a culture of Synechococcus sp. (strain 8809, isolated from Lake Constance by A. Ernst), with a mean cell volume (live) of $1.02 \mu^{3}$, length of $1.99 \mu \mathrm{m}$, and width of $0.83 \mu \mathrm{m}_{\text {; }}$ and (3) a culture of Chlorella minutissima (isolated from Plußsee by B. Meyer) with a mean cell volume (live) of $7.12 \mu^{3}$, and a diameter of $2.33 \mu \mathrm{m}$ (range 1.7 to $3.1 \mu \mathrm{m}$ ). All cell size measurements were carried out from pictures taken with a CCD camera connected to the microscope, and measured with an automated image analysis system (SIS $\mathrm{GmbH}$, Münster, Germany) after an image processing procedure (edge finding, digitalisation, etc.) similar to the one described by Massana et al. (1997). The prey items were added at a concentration of $6.1 \times 10^{4} \mathrm{ml}^{-1}$ (FLB), $4.5 \times 10^{4} \mathrm{ml}^{-1}$ (live Synechococcus sp.), and $2.3 \times$ $10^{4} \mathrm{ml}^{-1}$ (live Chlorella sp.). All the experiments, except the one with FLB, were run in 2 replicates at $16^{\circ} \mathrm{C}$. Samples were first fixed with alkaline Lugol's solution ( $2 \%$ final conc.) and 5 min later postfixed with formaldehyde ( $2 \%$ final conc.) (Sherr et al. 1989). The Lugol's colour was later cleared by adding a few drops of $3 \%$ thiosulfate. Appropriate volumes of each sample were filtered on black $3 \mu \mathrm{m}$ polycarbonate filters (Millipore), stained with DAPI (Porter \& Feig 1980), and the number of ingested food items of 40 to 60 ciliates counted in an epifluorescence microscope (Zeiss Axiophot). Live Synechococcus sp. and Chlorella minutissima could be clearly distinguished and counted in food vacuoles by their pigment autofluorescence.

We calculated ingestion rates as the slope of the linear regression of average number of prey items per cell versus time (based on 5 to 6 time points). After exposing the ciliates to the prey items for 60 to $90 \mathrm{~min}$, they were diluted 1:100 with sterile culture medium. Thereafter 5 to $6 \mathrm{~h}$ samples were taken and processed as described above to determine digestion of the prey items from changes in vacuole contents using fluores- cence microscopy (for details see Dolan \& Šimek 1997). Digestion rates were calculated as the slopes of the linear regression of $\log$ (\% time zero prey per cell) on the basis of 7 to 8 points. Multiplying the slope by 100 gives an exponential digestion rate constant, $K_{r}$ in units of \% min $^{-1}$ (Dolan \& Šimek 1997). Based on $K$, an expected halftime of cell content, $t_{1 / 2}$, was estimated by calculating the time (in minutes) required for a $50 \%$ decline in cell content (Dolan \& Šimek 1997).

Particle uptake experiments. Particle size selection and clearance rates were determined in short-term uptake experiments. To avoid strong interference of food particles, ciliates were taken from cultures at the end of the exponential phase when food concentrations were generally reduced to levels below $10^{4}$ algae $\mathrm{ml}^{-1}$. In one case, a ciliate culture, after prolonged ( $>5$ d) starvation with a food concentration below $2 \times$ $10^{3}$ algae ml ${ }^{-1}$, was also used for the experiments. The condition of the ciliates (motility, filtration activity) was always checked in live observations (dark field microscopy) before the experiments. The nutritional state of the ciliates was characterized by the ambient food concentration and the amount of algae visible in the food vacuoles.

To examine the effect of particle size on the ingestion kinetics, we used fluorescent latex microspheres of $0.22,0.47,1.0,1.8,2.73$, and $4.23 \mu \mathrm{m}$ diameter (Polyscience, Inc.). We intended to obtain the whole functional response curve for each particle size: the slope with rapidly increasing ingestion rates at low particle concentrations and saturated, maximal uptake rates at high concentrations. Therefore ciliates were incubated together with a series of 6 to 7 different concentrations of each microsphere size (in duplicate trials), in approximately geometrically increasing concentrations. We used an incubation time between 3 and $10 \mathrm{~min}$, depending on particle concentration, to allow ingested beads in the food vacuoles to be counted precisely. Samples were fixed and processed as described above for bacteria and algae as prey particles. Uptake rates were fitted numerically to a hyperbolic function using the software Sigmaplot (SPSS Inc., CA, USA) and maximum ingestion rates $\left(I_{\max }\right)$ and half-saturation constants $\left(K_{\mathrm{s}}\right)$ were obtained from the curve fit. Maximum clearance rate $\left(C_{\max }\right)$ was calculated by dividing $I_{\max }$ by $K_{\mathrm{s}}$.

In order to examine whether the ingestion of artificial particles is influenced by the presence of approximately similar sized natural prey particles, we performed uptake experiments with 1:1 mixtures of the pairs Synechococcus sp./1 $\mu \mathrm{m}$ beads $\left(4-5 \times 10^{5} \mathrm{ml}^{-1}\right)$ and Chlorella minutissima $/ 2.13 \mu \mathrm{m}$ beads $\left(6-8 \times 10^{4}\right.$ $\mathrm{ml}^{-1}$ ), and determined the ingestion rates for dual and single prey additions. The concentrations used were still in the linear increasing part of the functional 
response curves. For the comparison of single and dual prey trials we calculated the clearance rate for each particle type. Selection experiments were repeated for 3 cultures in different states of food satiation, characterized by the amount of algae in food vacuoles. All statistical analyses were performed with the software package Statistica (StatSoft Inc., Tulsa, OK, USA).

\section{RESULTS}

\section{Growth of Halteria cf. grandinella}

Long-term cultures of Halteria cf. grandinella could be maintained on the 2 flagellated phytoplankton species Rhodomonas minuta and Chlamydomonas reinhardii. The size range of Halteria cf. grandinella cells in our stock cultures was quite variable even when there was sufficient algae food. Live measurements yielded the following results (mean $\pm \mathrm{SD}$, range, $\mathrm{N}=$ 50): width $=18.7 \pm 1.6 \mu \mathrm{m}, 15.3$ to $21.5 \mu \mathrm{m}$; length $=$ $20.3 \pm 1.6 \mu \mathrm{m}, 16.9$ to $25.9 \mu \mathrm{m}$; volume $=3754 \pm$ $890 \mu^{3}, 2303$ to $5840 \mu^{3}$. This size range was shifted moderately towards larger sizes (mean length $=21$ to $22 \mu \mathrm{m}$ ) in freshly transferred and exponentially growing cultures and towards smaller cell sizes (mean length $=18$ to $19 \mu \mathrm{m}$ ) in starving cultures.

Best growth was on Rhodomonas minuta, and the concentration-dependent growth rates showed a typical hyperbolic numerical response (Fig. 1). Maximum growth rates were observed between 0.5 and $1.0 \times 10^{5}$ algae cells $\mathrm{ml}^{-1}$. The estimated parameters from the fit-

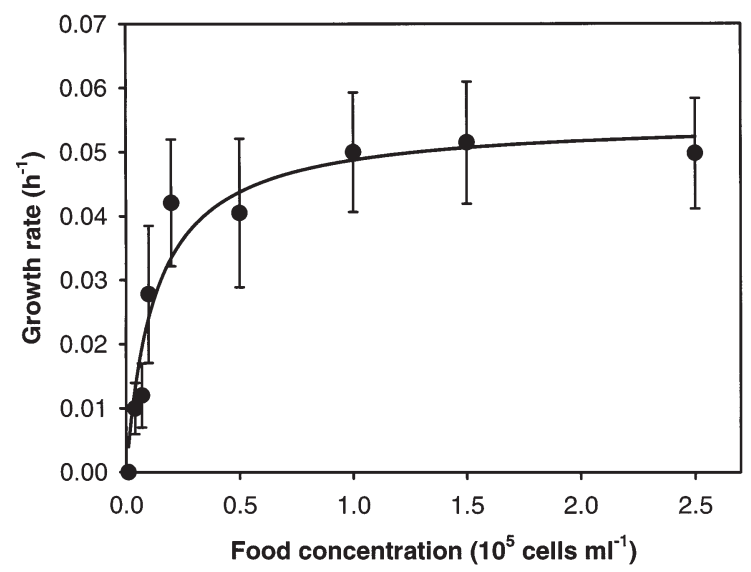

Fig. 1. Growth rate $(\mu)$ of Halteria cf. grandinella as a function of initial food concentration (Rhodomonas minuta). Symbols represent treatment means $\pm 1 \mathrm{SE}$. The curve represents a numerically fitted hyperbolic function. Estimated parameters from the non-linear regression are: maximum growth rate, $\mu_{\max }=0.06 \mathrm{~h}^{-1}$; half-saturation constant $K_{\mathrm{s}}=13 \times 10^{3}$ cells ml$^{-1}$ ted hyperbolic function were $0.06 \mathrm{~h}^{-1}\left(T_{2}=12 \mathrm{~h}\right)$ for the maximum growth rate $\left(\mu_{\max }\right)$ and $1.3 \times 10^{4}$ cells ml $^{-1}$ for $K_{\mathrm{s}}$. Growth rates for Chlamydomonas reinhardii were lower, with $\mu_{\max }$ at saturating food concentrations $(>1 \times$ $10^{5}$ cells ml-1) of ca $0.04 \mathrm{~h}^{-1}\left(T_{2}=17 \mathrm{~h}\right)$ However, for all particle uptake experiments, Halteria cf. grandinella was derived from cultures fed with $C$. reinhardii, as our stock culture of $R$. minuta had collapsed at that time.

We tried to raise Halteria cf. grandinella on other food organisms including mixed and pure cultures of bacteria, different strains of Synechococcus sp., and heterotrophic nanoflagellates. Although $H$. cf. grandinella could be maintained for several days on other food sources without a population decline, we were not successful in obtaining significant growth for a longer period on food organisms other than the 2 phytoflagellates Rhodomonas minuta and Chlamydomonas reinhardii. There were indications, however, that accompanying bacteria in the algae cultures were used as additional food sources. Bacterial concentration was generally reduced to $1-2 \times 10^{6} \mathrm{ml}^{-1}$, and bacteria were relatively homogenous in morphology, indicating that $H$. cf. grandinella substantially grazed on bacteria. For several cases where we analyzed the bacterial size structure in Halteria cultures with the image analysis system, bacteria were dominated by rods with a mean size of ca $1 \times 0.5 \mu \mathrm{m}$ and a mean volume in the range of 0.12 to $0.16 \mu^{3}$. A higher morphological diversity and a larger mean cell volume $\left(>0.2 \mu \mathrm{m}^{3}\right)$ was always observed in algal stock cultures without ciliates (data not shown).

\section{Digestion experiments}

Fig. 2 shows the results of ingestion and digestion experiments with Halteria cf. grandinella exposed to heat-killed FLB, live Synechococcus sp., and live Chlorella sp. Based on grazing rates over the first hour when uptake was roughly linear, calculated clearance rates (in $\mathrm{nl}$ ind. $^{-1} \mathrm{~h}^{-1}$ ) were 181 for FLB, 183 for Synechococcus sp, and 173 for Chlorella sp. Data from digestion experiments documented declines in food vacuole contents of $H$. cf. grandinella with time after cultures were diluted 1:100 with particle-freed culture medium. Slopes of the exponential declines of Synechococcus sp. and Chlorella sp. (Fig. 2B) were not significantly different (ANCOVA, F-test, p < 0.05), and only slightly different from the slope of decrease of FLB in food vacuoles ( $p>0.05)$. Digestion rate parameters given in Table 1 indicate the longest half-time of the ciliate vacuole content for FLB (128 min), compared to the significantly shorter half-times estimated for Synechococcus sp. (84 min) and Chlorella sp. (67 min) cells. 


\section{Particle-size-dependent functional response}

Feeding experiments with our natural food particles, bacteria (FLB), picocyanobacteria (Synechococcus sp.), and nano-sized algae (Chlorella minutissima),
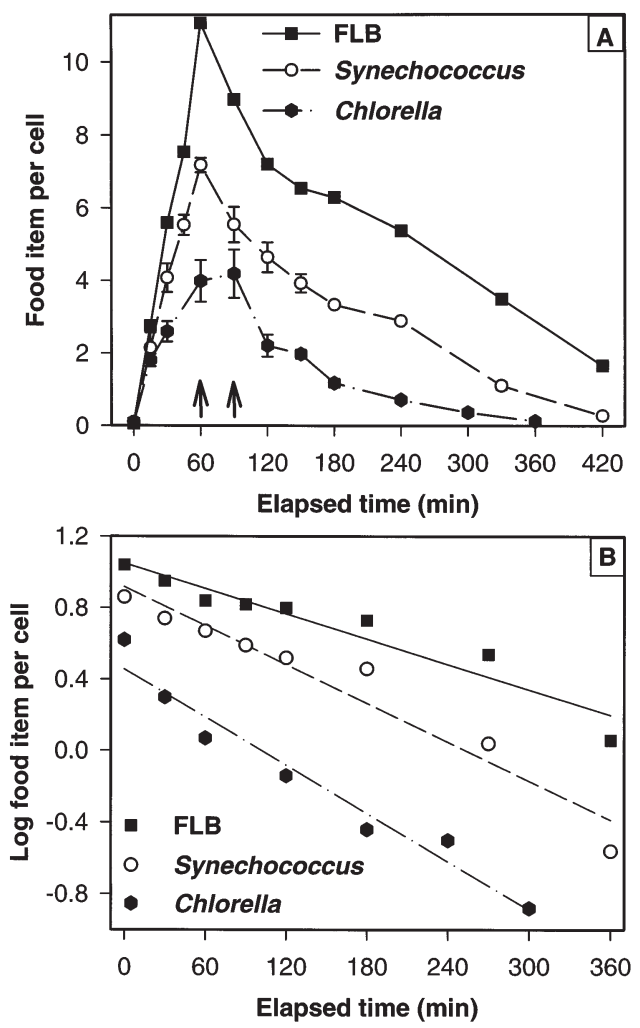

Fig. 2. (A) Data from ingestion/digestion experiments showing increase of food vacuole content of Halteria cf. grandinella with time following addition of fluorescently labelled bacteria (FLB), live Synechococcus sp., and live Chlorella minutissima Declines in food vacuole contents after dilution at 1:100 (marked by arrows), at time $60 \mathrm{~min}$ for FLB and Synechococcus sp., and at time $90 \mathrm{~min}$ for C. minutissima cells, indicate digestion of the food items with time (C. minutissima, Synechococcus sp.: means and ranges of 2 replicate trials, FLB: single trial). (B) Linear regression of decrease in ingested food items with time. Digestion rate parameters are given in Table 2 revealed that all were readily ingested, and their uptake was linear for up to $1 \mathrm{~h}$ (Fig. 2A). For uptake experiments with latex microspheres, we tried to keep the incubation times as short as possible to avoid the effects of possible particle rejection or satiation. No significant uptake could be detected for $0.22 \mu \mathrm{m}$ spheres, whereas for all other size classes a typical type-2 functional response was measured with linear increasing ingestion rates in the lower concentration range and maximal and satiated uptake rates at high concentrations.

Fig. 3 shows only the uptake rates and the fitted curves for the lower particle concentrations to better illustrate size-dependent differences. This is also the relevant concentration range for in situ conditions, and the initial slope in uptake rates corresponds to the affinity (and the maximum clearance rate) of the grazers to the respective particle type (Fenchel 1980c). The steepest increase in uptake rates was observed for $2.76 \mu \mathrm{m}$ beads, with gradually decreasing slopes for

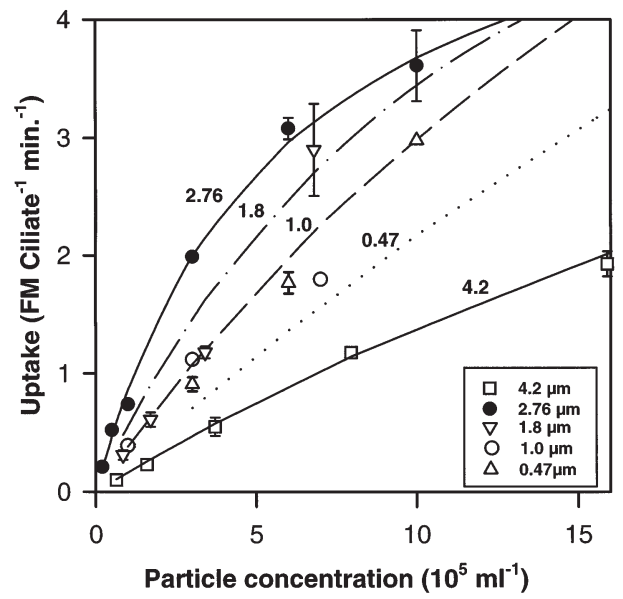

Fig. 3. Initial slopes of the functional response curves for Halteria cf. grandinella with particles of different diameters (FM: fluorescent microspheres). The lines are numerically fitted to a hyperbolic function (for the whole range of particle concentrations). Estimated parameters for maximum uptake rate $\left(I_{\max }\right)$ and $K_{\mathrm{s}}$ are given in Table 2. Symbols and error bars are means and ranges of 2 replicate trials

Table 1. Halteria cf. grandinella, summary of results from digestion experiments. Prey items were heat-killed, fluorescently labelled bacteria (FLB), live Synechococcus sp., and live Chlorella minutissima. Cell contents are the average number of prey per ciliate cell at the beginning of the digestion period. N: number of time-course samples (see Fig. 2). R-values are based on the linear regression of $\ln \left(\% t_{0}\right.$ cell content) versus time; probability levels given as ${ }^{* * *} \mathrm{p}=0.001$. K: digestion rate in $\%$ min ${ }^{-1}$, SE: standard error. Prey $t_{1 / 2}$ : estimated half-life in minutes of the ciliate food vacuole contents

\begin{tabular}{|lcccccc}
\hline Prey item & $\begin{array}{c}\text { Cell } \\
\text { contents }\end{array}$ & $\mathrm{N}$ & $\begin{array}{c}\text { No. of H. cf. grandinella } \\
\text { inspected per sample }\end{array}$ & $\mathrm{R}^{2}$ & $K(\mathrm{SE})$ & Prey $t_{1 / 2}$ \\
\hline FLB & 11.1 & 8 & 40 & $0.918^{* * *}$ & $0.83(0.08)$ \\
Synechococcus sp. & 7.2 & 8 & $>60$ & $0.941^{* * *}$ & $0.54(0.07)$ & 84 \\
Chlorella minutissima & 4.2 & 7 & 80 & $0.958^{* * *}$ & $1.03(0.10)$ & 67 \\
\hline
\end{tabular}


smaller and larger (4.2 $\mu \mathrm{m})$ particle sizes (Fig. 3). However, maximum ingestion rates were recorded for the smallest particle sizes, with ca $19(0.47 \mu \mathrm{m})$ and 13 $(1 \mu \mathrm{m})$ particles ciliate ${ }^{-1} \mathrm{~min}^{-1}$, respectively (Table 2 ).

There was a large heterogeneity in particle uptake rates among the Halteria cf. grandinella population. For $1 \mu \mathrm{m}$ beads for example, uptake at saturating concentrations was between 0 and 30 beads ciliate ${ }^{-1} \mathrm{~min}^{-1}$. The parameters $I_{\max } K_{\mathrm{s}}$ and $C_{\max }$ determined from the functional response, are therefore only average values for the whole population. To reveal the maximal feeding potential of $H$. cf. grandinella, we considered only the $10 \%$ of the population with the highest uptake rates. These highest uptake rates also could be fitted to a hyperbolic function, except for the $1 \mu \mathrm{m}$ beads, for which no saturation of ingestion rates was observed. The calculated $C_{\max }$ are 2 to 3 times higher than the average $C_{\max }$ and even 8 times higher in the case of the $2.76 \mu \mathrm{m}$ beads, the most efficiently ingested particle size (Table 2).

Maximum clearance rates followed a unimodal function of particle diameter with an optimum at the particle size $2.13 \mu \mathrm{m}$ (Fig. 4). For comparison, we included the calculated maximal clearance rates for the natural prey particles, obtained from uptake experiments at low particle concentrations. Although these food organisms are not exactly spherical, when positioned according to their equivalent spherical diameter (ESD) their clearance rates fit into the overall shape of the efficiency curve determined from the microsphere uptake experiments (Fig. 4).

The difference in the uptake rates between the particle sizes $1,1.8$ and $2.76 \mu \mathrm{m}$ becomes more visible when expressed as particle volume (Fig. 5A). In this case, the calculated ingestion, at similar particle concentration, is 3 to 4 times higher for $2.76 \mu \mathrm{m}$ than for $1 \mu \mathrm{m}$ particles, with $1.8 \mu \mathrm{m}$ beads in an intermediate position. The relative pattern of these functional response curves could be repeated with a Halteria cf. grandinella culture of an inferior physiological state,

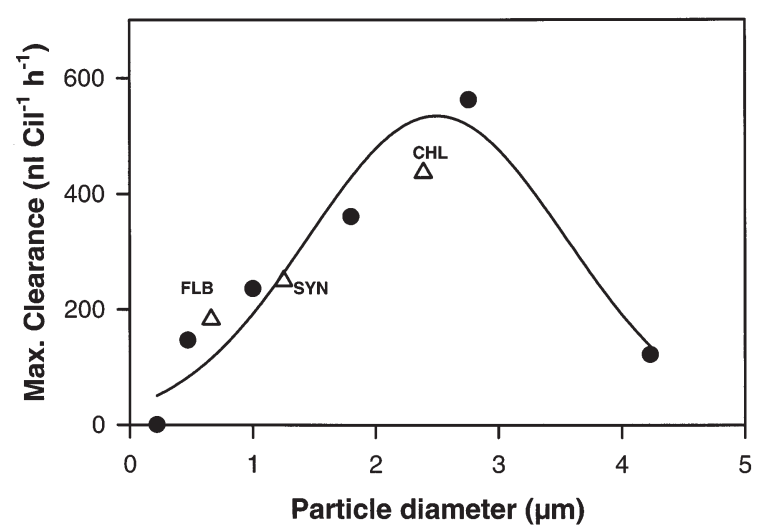

Fig. 4. Maximum clearance rates $\left(C_{\max }\right)$ of Halteria cf. grandinella as a function of particle diameter. $C_{\max }$ was calculated from the functional response curves with microspheres $(\bullet)$ and from ingestion measurements with FLB, Synechococcus sp. (SYN) and Chlorella minutissima (CHL) at low prey concentrations $(\Delta)$. FLB, SYN and CHL are positioned according to their equivalent spherical diameter. Curve is fitted with a Gaussian peak equation

obtained after several days of starvation. These ciliates ingested all particle sizes in a similar order of efficiency to the cells from an exponentially growing culture, but with nearly 10 -fold reduced uptake rates (Fig. 5B). Cell volume of long-term starved ciliates was reduced to about $60 \%$ of that of cells from cultures starved for a short period. These drastically reduced ingestion rates were not due to an increased proportion of cells with zero uptake, but due to reduced individual ingestion rates. This is exemplified for one concentration of $1.8 \mu \mathrm{m}$ beads in Fig. 6. Whereas more than $70 \%$ of ciliates with a better physiological state had ingested 10 or more microspheres (Fig. 6A), the main portion of the starved cells had ingested only 1 to 7 microspheres (Fig. 6B). The frequency distribution of the number of ingested beads generally followed a Normal distribution for higher particle concentrations, and a Poisson distribution when using low particle concentrations.

Table 2. Summary of bead ingestion experiments. Estimates $( \pm \mathrm{SE})$ of maximum ingestion rates $\left(I_{\max }\right)$ and half-saturation constants $\left(K_{\mathrm{s}}\right)$ were obtained from non-linear curve fitting. Maximum clearance rates $\left(C_{\max }\right)$ were calculated from $I_{\max }$ and $K_{\mathrm{s}}$. $C_{\max }$ $(10 \%)$ was calculated for the $10 \%$ of the population with the highest uptake rates. All parameters derived from the non-linear regressions were significant $(\mathrm{p}<0.05)$ except $K_{\mathrm{s}}$ for $0.47 \mu \mathrm{m}$ beads

\begin{tabular}{|lcccc|}
\hline $\begin{array}{l}\text { Diameter } \\
(\mu \mathrm{m})\end{array}$ & $\begin{array}{c}I_{\max } \\
\left(\text { particles ciliate } \mathrm{min}^{-1}\right)\end{array}$ & $\begin{array}{c}K_{\mathrm{s}} \\
\left(10^{5} \text { particles ml }^{-1}\right)\end{array}$ & $\begin{array}{c}C_{\max } \\
\left(\mu l \text { ciliate }^{-1} \mathrm{~h}^{-1}\right)\end{array}$ & $\begin{array}{c}C_{\max }(10 \%) \\
\left(\mu l \mathrm{ciliate}^{-1} \mathrm{~h}^{-1}\right)\end{array}$ \\
\hline 0.22 & 0 & 0 & 0 & 0 \\
0.47 & $19.1(5.3)$ & $78.0(34.6)$ & 0.15 & 0.36 \\
1.0 & $12.7(2.2)$ & $32.3(11.1)$ & 0.24 & 0.54 \\
1.8 & $8.0(0.7)$ & $13.4(2.9)$ & 0.36 & 0.83 \\
2.76 & $5.8(0.1)$ & $5.6(0.3)$ & 0.12 & 0.90 \\
4.23 & $5.5(0.6)$ & $27.5(6.2)$ & & 0.28 \\
\hline
\end{tabular}



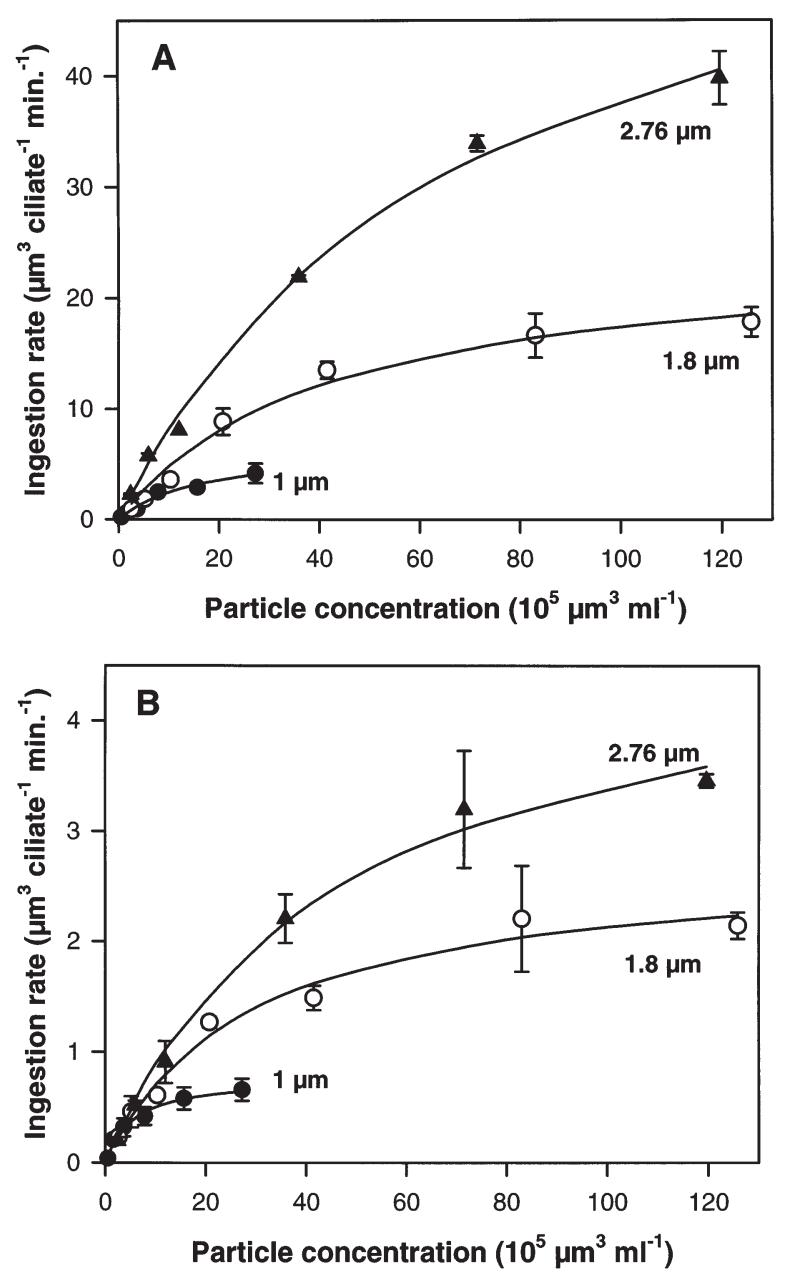

Fig. 5. Functional response curves expressed as particle volume for Halteria cf. grandinella obtained from 2 different nutritional states: (A) shortly after food depletion; (B) after long-term starvation. Curves represent numerically fitted hyperbolic functions. Note 10-fold difference between (A) and (B) in scale of $y$-axis

\section{Particle selection experiment}

In dual prey ingestion experiments, Halteria cf. grandinella was offered artificial and natural prey particles simultaneously (approx. 1:1 ratio, non-saturating food concentrations), and the clearance rates were compared to single prey experiments. This should give evidence concerning whether there is an interference between different particles due, for example, to selection behaviour. This was done with $3 H$. cf. grandinella cultures of different nutritional states, characterized by the amount of algae in the food vacuoles. One culture (A) was well fed (3.2 algae ciliate ${ }^{-1} ; 78 \%$ of ciliates with ingested algae), one was at the end of the exponential phase $\left(B_{;} 1.3\right.$ algae ciliate ${ }^{-1}, 59 \%$ with ingested algae), and one was starved $\left(C_{;} 0.2\right.$ algae ciliate ${ }^{-1}, 17 \%$
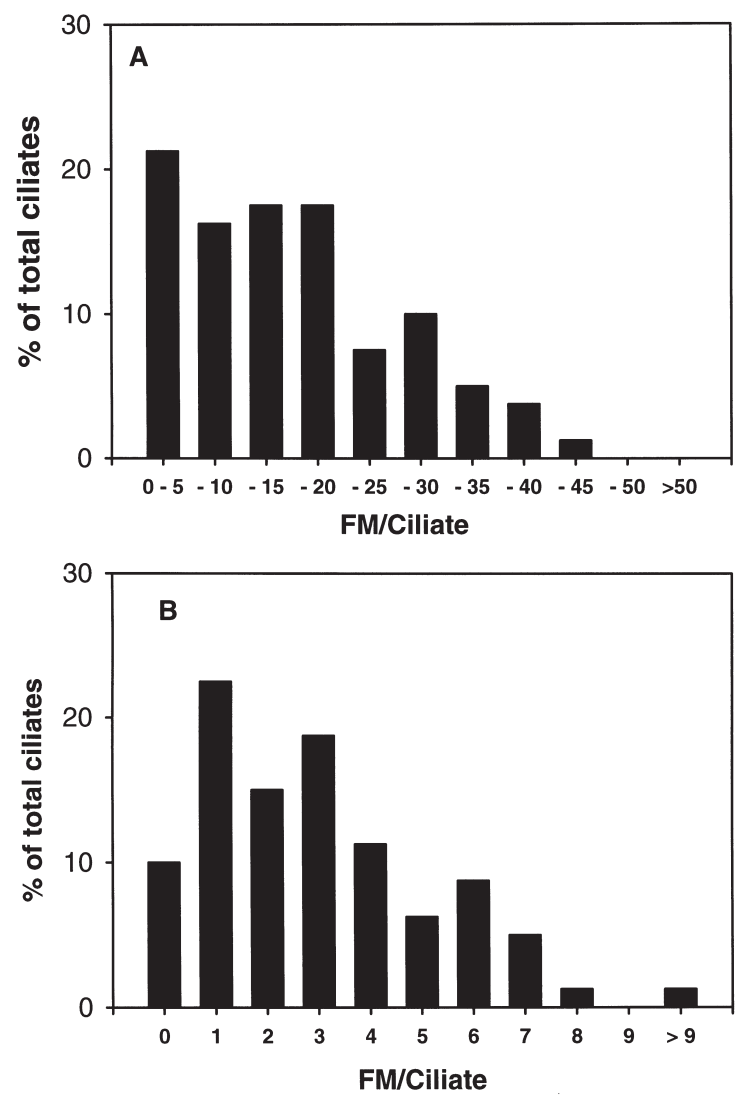

Fig. 6. Example of the frequency distribution of ingested beads $\left(1.8 \mu \mathrm{m} ; 3.4 \times 10^{5} \mathrm{ml}^{-1} ; 10 \mathrm{~min}\right.$ incubation $)$ per ciliate in uptake experiments corresponding to Fig. 3 ; ciliate cultures were (A) from the end of the exponential phase, (B) from the stationary phase

with ingested algae). The interference of similar sized artificial or natural prey particles on the ingestion rates of each other seemed to be rather low (Fig. 7). In only 2 of the paired prey additions (Synechococcus sp., $H$. cf. grandinella cultures A and B) were the calculated clearance rates significantly higher compared to single prey additions $(t$-test, $\mathrm{p}<0.05)$. The other differences in clearance rates between dual and single prey additions were not significant. However, the overall variability between the 3 replicate trials for measuring ingestion rates might have been too high to detect small differences. The mean coefficient of variation for all uptake experiments shown in Fig. 7 (n = 18) was $14 \%$, with a range of 2 to $35 \%$.

\section{DISCUSSION}

\section{Particle-size-dependent feeding efficiency}

The suitability of artificial particles for examining size-dependent feeding efficiencies in filter-feeding 


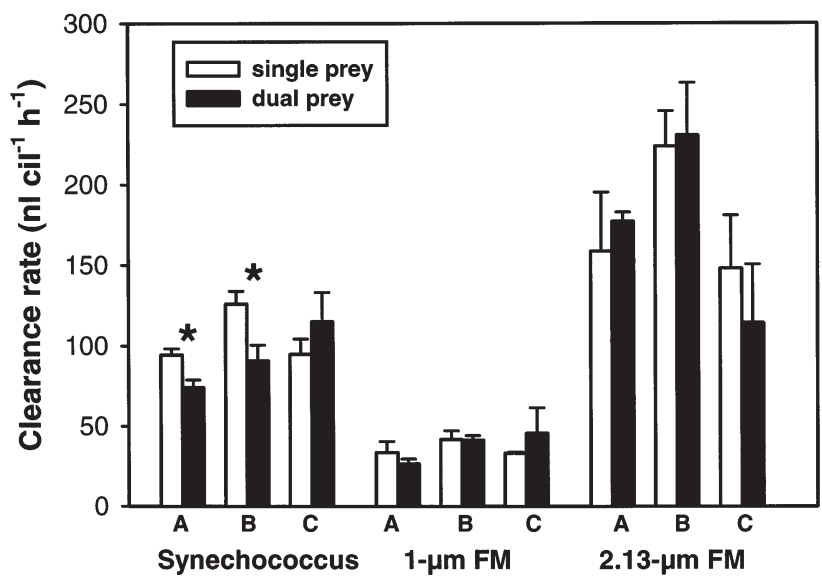

Fig. 7. Comparison of clearance rates with single and dual prey (ca 1:1 mixtures) additions. Synechococcus: single and together with $1 \mu \mathrm{m}$ beads; $1 \mu \mathrm{m}$ beads: single and with Synechococcus sp.; $2.13 \mu \mathrm{m}$ beads: single and with Chlorella sp. A, $\mathrm{B}$, and $\mathrm{C}$ correspond to 3 Halteria cf. grandinella cultures derived from increasing starvation conditions (A: satiated, B: briefly starved, C: longer starvation). Values are means $\left( \pm 1\right.$ SD) from 3 replicate trials ( ${ }^{*}$ significant differences between single and dual prey experiments; $\mathrm{p}<0.05$ )

ciliates has been supported in previous studies (Fenchel 1980c, 1986). Clearance rates measured in particle uptake experiments were shown to be comparable to the theoretically expected ones from current velocities and filtering area (Jonsson 1986, Fenchel \& Jonsson 1988). The fluorescent microspheres were also an appropriate tool for examining particle size selection in Halteria cf. grandinella. The ingestion rates as a function of particle concentration could be closely fitted to a hyperbolic functional response curve which is analogous to the type-2 model (Holling 1959). It has been shown before that this pattern has a mechanistic basis in the sense that suspension feeders process a constant volume of water per time. At low particle concentrations the uptake increases linearly with particle concentration, whereas at higher concentrations the time to phagocytose and digest a prey particle becomes limiting (Fenchel 1980c).

We measured the functional response of different particle sizes primarily to evaluate the size-dependent feeding efficiency of Halteria cf. grandinella. As in many other comparable experimental studies which measured feeding rates, we used short-term incubations in order to measure uptake rates precisely. Further, ciliates were taken from short-term starved cultures which have a high feeding capacity. Therefore, these rates must be interpreted as a maximum consumption potential of the ciliates, rather than as steady-state feeding rates. It has been shown that feeding rates drop when ciliates become gradually food satiated (Pfister \& Arndt 1998), and the extrapolation to hourly feeding rates would probably, at least for the large particle sizes, overestimate grazing rates. In situ measurements of picoplankton ingestion and clearance rates of $H$. cf. grandinella are, however, close to the ones measured here for the small particle sizes (e.g., up to $1600-3000$ bacteria ind. ${ }^{-1} \mathrm{~h}^{-1}$; Šimek et al. 1995, Table 1 in Šimek et al. 2000).

Our results clearly show that Halteria cf. grandinella is able to ingest a particle size range from larger sized bacteria $(0.5 \mu \mathrm{m}$ diameter $)$ to nano-sized algae $(4.2 \mu \mathrm{m})$. The decline of clearance rates between 0.5 and $0.2 \mu \mathrm{m}$ indicates that probably only the smallest planktonic bacteria cannot be retained by $H$. cf. grandinella. The maximum feeding efficiency is achieved for particles in the size range 2 to $3 \mu \mathrm{m}$, which indicates an adaptation towards small algae, including picocyanobacteria and eucaryotic picoalgae, as preferred food particles.

The spherical microspheres are not directly comparable with the shapes of bacteria and algae, and the size spectra of naturally ingested particles might deviate from the one characterizing bead uptake. We would expect that for natural particles the ingestion efficiency would be shifted slightly towards smaller particle volumes, as the maximum diameter (and not ESD) might determine retention efficiency. The fact that the clearance rates which we determined for FLB, Synechococcus sp. and Chlorella minutissima fit into the overall particle size spectra implies, however, that these spectra are a good estimation of the overall particle retention ability of $H$. cf. grandinella.

The particle size preference of Halteria cf. grandinella is comparable to those found for small marine oligotrichous ciliates. The maximum clearance rate for a cultured Strombidium vestitum (volume $=8900 \mu^{3}$ ) was obtained with $2.11 \mu \mathrm{m}$ beads (Jonsson 1986) and for Strombidium sulcatum (volume $=6500$ to $8900 \mathrm{~m}^{3}$ ) with $2.83 \mu \mathrm{m}$ beads (Fenchel \& Jonsson 1988), or with $2.5 \mu \mathrm{m}$ sized algae (Bernard \& Rassoulzadegan 1990). For a $20 \mu \mathrm{m}$ Strombidium sp. in field samples from the Baltic Sea, preferred particle size was 1.4 to $2.8 \mu \mathrm{m}$ (Kivi \& Setälä 1995).

The maximum clearance rates for Halteria cf. grandinella (with $2.76 \mu \mathrm{m}$ beads) are ca 10 times lower than those determined for Strombidium sulcatum (Bernard \& Rassoulzadegan 1990) or for small, marine oligotrichs in field samples (Kivi \& Setälä 1995). However, considering the most actively ingesting portion of the $H$. cf. grandinella population, a $C_{\max }$ of $4.9 \mu$ ciliate $^{-1}$ $\mathrm{h}^{-1}$ (with $2.76 \mu \mathrm{m}$ beads) would be comparable to the rates reported for small oligotrichs in the literature.

We did not find evidence for selective prey uptake by Halteria cf. grandinella based on properties other than particle size. The fact that the presence of other 
prey particles in the dual prey ingestion experiments did not result in significant changes in ingestion rates (Fig. 7) supports the view that $H$. cf. grandinella is an unselective filter feeder. Fenchel $(1980 a, b)$ showed that the basis for particle size selection in polyhymenophoran ciliates is the morphological structure of the mouth apparatus in which the space between the membranelles determines the minimum particle size which can be retained.

Prey size is certainly the most important property which determines feeding efficiency. However, several studies with marine oligotrichs revealed that qualitatively different particles of similar size are ingested at different rates (Verity 1991, Christaki et al. 1998) and uptake rates of filter-feeding ciliates might be modulated by other particle attributes such as surface charge or chemical cues (Sanders 1988, Stoecker 1988, Christaki et al. 1998). However, the capability for active selection among different particles is very restricted in filter-feeding oligotrichs. For an interpretation of observed differences in uptake rates, the potential differences in encounter rates, handling times, and digestion efficiencies must also be considered (Verity 1991). True active selection behaviour has been found only in the tintinnid Favella, which can actively reject unfavourable particles from the peristomial cavity (Taniguchi \& Takeda 1988, Stoecker et al. 1995). An adaptation of feeding behaviour might be seen when the filtration activity (movement of the responsible membranelles) can be directly measured (e.g., by high-speed video recording).

\section{Feeding heterogeneity in Halteria cf. grandinella populations}

We observed a large heterogeneity in individual feeding rates, with the maximum clearance and ingestion rates being several-fold higher for the most actively feeding part of the population (Table 2). This heterogeneity might be due to the coexistence of physiologically different clones, or to ciliates in different phases of the cell cycle, with possibly different physiological states. The highest particle uptake rates were found with cells at the end of the exponential growth phase shortly after food depletion, but not after longer periods of starvation (Fig. 6). The impact of the physiological state on feeding heterogeneity has been studied in the ciliate Tetrahymena pyriformis (Hatzis et al. 1994). In that study, comparable to results with Halteria cf. grandinella, highest clearance rates and highest heterogeneity were found during short-term starvation, whereas clearance rates were reduced and more uniform for stationary phase populations.
If we take into account that bacteria and detritus also serve as potential food sources, then the batch culture conditions are not as defined as the algal food concentration alone might suggest. Even more pronounced heterogeneity, which cannot be explained only by differences in ambient water temperature, was found in feeding rates of natural populations of Halteria cf. grandinella in 2 eutrophic reservoirs (Šimek et al. 2000). The heterogeneity in feeding rates did not affect the conclusions on the prey size spectrum of $H$. cf. grandinella, as this was independent of the feeding rates (Fig. 5). For the absolute values of the ingestion and clearance rates we have to be aware, however, that they depend on different factors and can vary considerably even within the same population.

In experimental studies with cultured protists, it is becoming increasingly evident that many autecological characters, especially feeding-related parameters, depend on the culturing history and the physiological state of the organisms. It has been shown that feeding rates (Zubkov \& Sleigh 1996), chemosensory response (Snyder 1991) and food selectivity (Jürgens \& DeMott 1995) change with the physiological state of the grazers. In addition to the impact of the physiological and nutritional state on the feeding characteristics, interclonal differences occur, which have been demonstrated for several ciliate taxa with respect to growth rates (Pérez-Uz 1995).

\section{Growth and food requirements of Halteria cf. grandinella}

The estimated maximum growth rate of Halteria cf. grandinella $\left(1.44 \mathrm{~d}^{-1}\right.$, at $\left.16.5^{\circ} \mathrm{C}\right)$, when growing on Rhodomonas minuta, is within the range found for in situ growth for this ciliate species. Maximal observed net growth rates of $H$. cf. grandinella in predator exclusion experiments were $0.80 \mathrm{~d}^{-1}$ in the meso-eutrophic Ř́mov Reservoir $\left(T=20^{\circ} \mathrm{C}\right)$ (Macek et al. 1996), and 1.64 to $1.9 \mathrm{~d}^{-1}$ in a hypertrophic, shallow lake ( $T=21$ to $23^{\circ} \mathrm{C}$ ) (Jürgens et al. 1999, for a summary see also Table 2 in Šimek et al. 2000).

In contrast to the marine oligotrichous Strombidium sulcatum (Rivier et al. 1985), Halteria cf. grandinella could not be maintained on a pure bacterial diet. This is in accordance with the study by Skogstad et al. (1987), who could maintain a Halteria sp. (a species with algal endosymbionts) on a variety of phytoplankton species, with best growth on crypromonads, but not on heterotrophic bacteria or cyanobacteria. However, Taylor (1978) was able to grow a Halteria species on a pure bacterial culture. From an energetic point of view, there is no reason why growth of $H$. cf. grandinella is not supported by (large-sized) heterotrophic 
bacteria or Synechococcus sp. at high food concentrations. By using the ingestion rate data with $1 \mu \mathrm{m}$ beads and an assumed gross growth efficiency of $30 \%$, we calculated that, at a food concentration of $10^{7}$ picoplankton cells $\mathrm{ml}^{-1}, H$. cf. grandinella should be able to achieve a population doubling time of ca $30 \mathrm{~h}$ (Šimek et al. 2000). Similar conclusions were made from bacterial ingestion data in field experiments (Šimek et al. 1996).

However, besides the carbon input rates, the digestion and assimilation efficiency might also vary between different food particles. From our ingestion/digestion experiments with bacteria, cyanobacteria, and algae, we did not obtain strong evidence for a differential use of algae and bacteria, although the digestion rates were slightly lower for FLB (Fig. 2). Digestion efficiency can vary, however, for different bacterial strains and FLB might deviate in this respect from live bacteria. Biochemical growth limitation (e.g., by essential fatty acids) has been demonstrated for mesozooplankton (Müller-Navarra 1995), and the lack of essential compounds might also be a reason for the inadequacy of bacteria to enable growth of Halteria cf. grandinella. Thus, while algal food may not necessarily be the dominant source of carbon for $H$. cf. grandinella under natural plankton conditions (Šimek et al. 2000), it seems to be essential for high growth rates.

\section{Importance of Halteria cf. grandinella as a consumer of pico- and nanoplankton}

Similar to marine coastal environments, in which small, oligotrichous ciliates have been identified as a major component of protozooplankton (Smetacek 1981, Vaqué et al. 1997), oligotrichs are a numerically important ciliate group in freshwater plankton (e.g., Beaver \& Crisman 1989, Müller 1989, Macek et al. 1996). They can dominate in oligotrophic systems, here with mixotrophy as an adaptation (Stoecker et al. 1987, Bernard \& Rassoulzadegan 1994, Laybourn-Parry 1994), as well as in eutrophic systems, where they benefit from the wide prey spectrum they can exploit. Small freshwater oligotrichs are mainly represented by the taxa Halteria, Pelagohalteria and Strobilidium (now Rimostrombidium) (Foissner et al. 1999). For these genera, high ingestion rates of hetero- and autotrophic picoplankton have been measured with fluorescently labelled prey particles (Šimek et al. 1995, 1996, Stabell 1996). Especially the bacterial consumption of Halteria, most probably $H$. cf. grandinella, can account for a major portion of total protozoan bacterivory (Šimek et al. 1995, 2000). Based on the measured ingestion rates of bacteria and picoalgae, it has been argued that Halteria could achieve relatively high growth rates on a pure diet of picoplankton (Šimek et al. 1996).

The measured size-dependent differences in particle uptake in our experiments suggest, however, that Halteria cf. grandinella is an omnivorous filter feeder with a feeding preference for nanoplanktonic organisms. To illustrate the potential contribution of different food particles, we used the functional response data with realistic in situ concentrations of bacteria, autotrophic picoplankton and nanoalgae in meso-eutrophic lakes (Fig. 8). The microsphere size $2.76 \mu \mathrm{m}$ corresponds to the size of nanoalgae for which we considered a concentration range of 20 to $100 \times 10^{3} \mathrm{ml}^{-1}$. The $1 \mu \mathrm{m}$ beads correspond (in volume) to the mean size of Synechococcus sp. (e.g., Šimek et al. 1995), for which we considered concentrations between 0.5 and $20 \times 10^{5}$ as realistic (e.g., Weisse 1993). The $0.47 \mu \mathrm{m}$ beads correspond in volume to the mean size of planktonic bacteria, and we considered a concentration range of 2 to $20 \times 10^{6} \mathrm{ml}^{-1}$. It is obvious that for the whole particle (and biovolume) concentration range, $H$. cf. grandinella would derive the major portion of its food from nanophytoplankton. APP could be significant at high concentrations, whereas bacteria would account only for a small portion of ingested matter despite high bacterial consumption rates (Fig. 8). However, natural situations can significantly deviate from this model due to
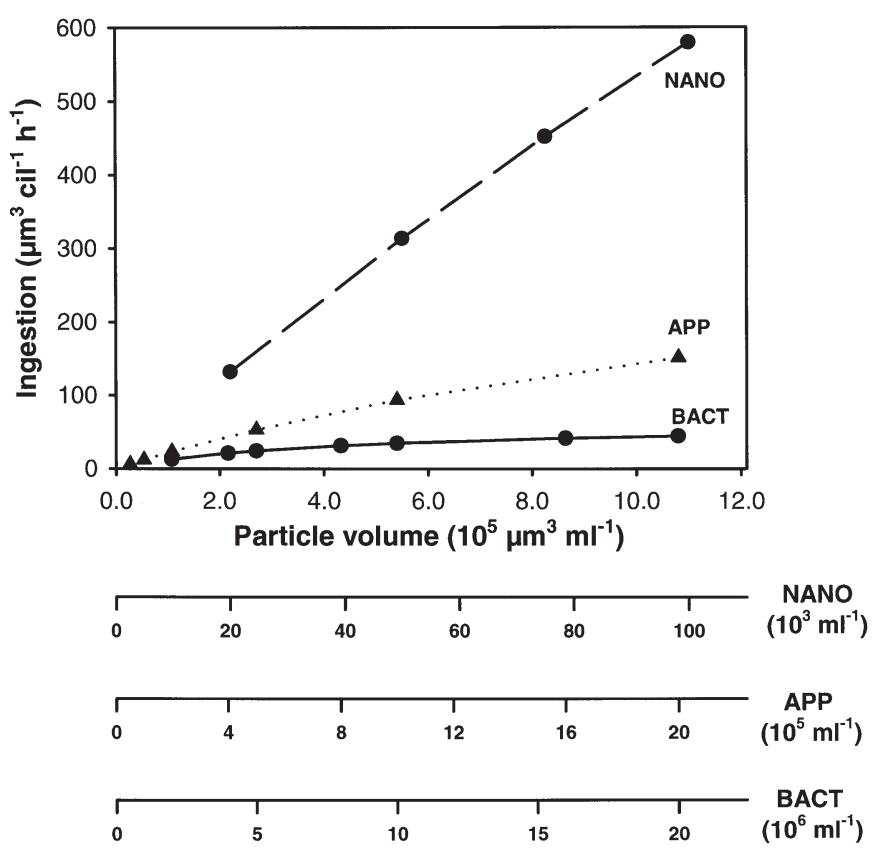

Fig. 8. Assumed ingestion of nanoplankton (NANO), autotrophic picoplankton (APP) and heterotrophic bacteria (BACT) by Halteria cf. grandinella across a concentration range found in meso- to eutrophic lakes. For further explanations see text 
different proportions of the actual food spectrum found. For instance, in the Sau Reservoir where Halteria spp. was quite abundant (up to 105 ind. $\mathrm{ml}^{-1}$ ), picoalgae had only very low abundance (Šimek et al. 2000). However, this system has increased concentrations of large bacteria, bacterial filaments and flocs, and detritus particles (Šimek unpubl. obs.) which potentially serve as additional food for Halteria spp.

Omnivorous feeding seems to be widespread among planktonic and benthic ciliates (Fenchel 1986, Pfister \& Arndt 1998) and has to be considered when defining the functional role of planktonic ciliates. By using the whole particle size range from 0.5 to $5 \mu \mathrm{m}$ efficiently, Halteria cf. grandinella feeds on several trophic levels (bacteria, nanoprotists, algae, detritus). This might be a selective advantage compared to specialized bacterivorous and algivorous ciliates and result in the widespread occurrence and often numerical dominance of Halteria spp. in freshwater plankton.

Acknowledgements. This study was supported by the GA CR research grant 206/99/0028 awarded to K.S. and by the Max Planck Society. We wish to thank N. Karstens, A. Montoro Wilck and Y. Harder for technical assistance and W. Foisnner for taxonomical advice.

\section{LITERATURE CITED}

Archbold JHG, Berger J (1985) A qualitative assessment of some metazoan predators of Halteria grandinella, a common freshwater ciliate. Hydrobiologia 126:97-102

Beaver JR, Crisman TL (1989) The role of ciliated protozoa in pelagic freshwater ecosystems. Microb Ecol 17:111-136

Bernard C, Rassoulzadegan F (1990) Bacteria or microflagellates as a major food source for marine ciliates: possible implications for the microzooplankton. Mar Ecol Prog Ser 64:147-155

Bernard C, Rassoulzadegan F (1994) Seasonal variations of mixotrophic ciliates in the Northwest Mediterranean Sea. Mar Ecol Prog Ser 108:295-301

Burkill PH, Edwards ES, John AWG, Sleigh MA (1993) Microzooplankton and their herbivorous activity in the Northeastern Atlantic Ocean. Deep-Sea Res 40:479-493

Carrias JF, Amblard C, Bourdier G (1998) Seasonal dynamics and vertical distribution of planktonic ciliates and their relationship to microbial food resources in the oligomesotrophic Lake Pavin. Arch Hydrobiol 143:227-255

Carrick HJ, Fahnenstiel GL (1990) Protozoa in Lakes Huron and Michigan: seasonal abundance and composition of ciliates and dinoflagellates. J Great Lakes Res 16:319-329

Christaki U, Dolan JR, Pelegri S, Rassoulzadegan F (1998) Consumption of picoplankton-size particles by marine ciliates - effects of physiological-state of the ciliate and particle quality. Limnol Oceanogr 43:458-464

Cleven EJ (1996) Indirectly fluorescently labelled flagellates (IFLF): a tool to estimate the predation on free-living heterotrophic flagellates. J Plankton Res 18:429-442

Dolan JR, Šimek K (1997) Processing of ingested matter in Strombidium sulcatum, a marine ciliate (Oligotrichida). Limnol Oceanogr 42:393-397
Fenchel T (1980a) Relation between particle size selection and clearance in suspension-feeding ciliates. Limnol Oceanogr 25:733-738

Fenchel T (1980b) Suspension feeding in ciliated protozoa: feeding rates and their ecological significance. Microb Ecol 6:13-25

Fenchel T (1980c) Suspension feeding in ciliated protozoa: functional response and particle size selection. Microb Ecol 6:1-11

Fenchel T (1986) Protozoan filter feeding. Prog Protistol 1: 65-113

Fenchel T, Jonsson P (1988) The functional biology of Strombidium sulcatum, a marine oligotrich ciliate (Ciliophora, Oligotrichina). Mar Ecol Prog Ser 48:1-15

Foissner W (1994) Progress in taxonomy of planktonic freshwater ciliates. Mar Microb Food Webs 8:9-35

Foissner W, Berger H, Schaumburg J (1999) Identification and ecology of limnetic plankton ciliates. Informationsberichte des Bayer. Landesamtes für Wasserwirtschaft, Heft 3/99, Bavarian State Office for Water Management, Munich

Gilbert JJ (1994) Jumping behavior in the oligotrich ciliates Strobilidium velox and Halteria grandinella, and its significance as a defense against rotifer predators. Microb Ecol 27:189-200

Guillard R, Lorenzen C (1972) Yellow-green algae with chlorophyllide c. J Phycol 8:10-14

Hatzis C, Srienc F, Fredrickson AG (1994) Feeding heterogeneity in ciliate populations: effects of culture age and nutritional state. Biotechnol Bioeng 43:371-380

Holling CS (1959) Some characteristics of simple types of predation and parasitism. Can Entomol 91:385-398

Jonsson PR (1986) Particle size selection, feeding rates and growth dynamics of marine planktonic oligotrichous ciliates (Ciliophora: Oligotrichina). Mar Ecol Prog Ser 33: 265-277

Jürgens K, DeMott WR (1995) Behavioral flexibility in prey selection by bacterivorous nanoflagellates. Limnol Oceanogr 40:1503-1507

Jürgens K, Arndt H, Rothhaupt KO (1994) Zooplankton-mediated changes of bacterial community structure. Microb Ecol 27:27-42

Jürgens K, Wickham SA, Rothhaupt KO, Santer B (1996) Feeding rates of macro- and microzooplankton on heterotrophic nanoflagellates. Limnol Oceanogr 41: 1833-1839

Jürgens K, Skibbe O, Jeppesen E (1999) Impact of metazooplankton on the composition and population dynamics of planktonic ciliates in a shallow, hypertrophic lake. Aquat Microb Ecol 17:61-75

Kivi K, Setälä O (1995) Simultaneous measurement of food particle selection and clearance rates of planktonic oligotrich ciliates (Ciliophora: Oligotrichina). Mar Ecol Prog Ser 119:125-137

Laybourn-Parry J (1994) Seasonal successions of protozooplankton in freshwater ecosystems of different latitudes. Mar Microb Food Webs 8:145-162

Macek M, Šimek K, Pernthaler J, Vyhnalek V, Psenner R (1996) Growth rates of dominant planktonic ciliates in two freshwater bodies of different trophic degree. J Plankton Res 18:463-481

Massana R, Gasol JM, Björnsen PK, Blackburn N, Hagström A, Hietanen S, Hygum BH, Kuparinen J, Pedrós-Alió C (1997) Measurement of bacterial size via image analysis of epifluorescence preparations - description of an inexpensive system and solutions to some of the most common problems. Sci Mar 61:397-407

Müller H (1989) The relative importance of different ciliate taxa in the pelagic food web of Lake Constance. Microb 
Ecol 18:261-273

Müller-Navarra DC (1995) Biochemical versus mineral limitation in Daphnia. Limnol Oceanogr 40:1209-1214

Pace ML, Orcutt JDJ (1981) The relative importance of protozoans, rotifers, and crustaceans in a freshwater zooplankton community. Limnol Oceanogr 26:822-830

Pérez-Uz B (1995) Growth rate variability in geographically diverse clones of Uronema (Ciliophora, Scuticociliatida). FEMS Microbiol Ecol 16:193-203

Pfister G, Arndt H (1998) Food selectivity and feeding behaviour in omnivorous filter-feeding ciliates: a case study for Stylonychia. Eur J Protistol 34:446-457

Porter KG, Feig YS (1980) The use of DAPI for identifying and counting aquatic microflora. Limnol Oceanogr 25:943-947

Rivier A, Brownlee DC, Sheldon RW, Rassoulzadegan F (1985) Growth of microzooplankton: a comparative study of bactivorous zooflagellates and ciliates. Mar Microb Food Webs 1:51-60

Sanders RW (1988) Feeding by Cyclidium sp. (Ciliophora, Scuticociliatida) on particles of different sizes and surface properties. Bull Mar Sci 43:446-457

Sanders RW, Porter KG, Bennett SJ, DeBiase AE (1989) Seasonal patterns of bacterivory by flagellates, ciliates, rotifers, and cladocerans in a freshwater planktonic community. Limnol Oceanogr 34:673-687

Sherr BF, Sherr EB, Fallon RD (1987) Use of monodispersed, fluorescently labeled bacteria to estimate in situ protozoan bacterivory. Appl Environ Microbiol 53:958-965

Sherr BF, Sherr EB, Pedrós-Alió C (1989) Simultaneous measurement of bacterioplankton production and protozoan bacterivory in estuarine water. Mar Ecol Prog Ser 54: 209-219

Sherr EB, Sherr BF (1987) High rates of consumption of bacteria by pelagic ciliates. Nature 325:710-711

Šimek K, Bobkova J, Macek M, Nedoma J, Psenner R (1995) Ciliate grazing on picoplankton in a eutrophic reservoir during the summer phytoplankton maximum: a study at the species and community level. Limnol Oceanogr 40: $1077-1090$

Šimek K, Macek M, Pernthaler J, Straskrabova V, Psenner R (1996) Can freshwater planktonic ciliates survive on a diet of picoplankton. J Plankton Res 18:597-613

Šimek $K$, Jürgens $K$, Nedoma J, Comerma $M$, Armengol J (2000) Ecological role and bacterial grazing of Halteria spp: small freshwater oligotrichs as dominant pelagic ciliate bacterivores. Aquat Microb Ecol 22:43-56

Skogstad A, Granskog L, Klaveness D (1987) Growth of freshwater ciliates offered planktonic algae as food. J Plankton Res 9:503-512

Editorial responsibility: John Dolan,

Edgewater, Maryland, USA
Smetacek V (1981) The annual cycle of protozooplankton in the Kiel Bight. Mar Biol 63:1-11

Snyder RA (1991) Chemoattraction of a bactivorous ciliate to bacteria surface compounds. Hydrobiologia 215:205-214

Sommaruga R, Psenner R (1993) Nanociliates of the order Prostomatida: their relevance in the microbial food web of a mesotrophic lake. Aquat Sci 55:179-187

Stabell T (1996) Ciliate bacterivory in epilimnetic waters. Aquat Microb Ecol 10:265-272

Stoecker DK (1988) Are marine planktonic ciliates suspension-feeders? J Protozool 35:252-255

Stoecker DK, Michaels AE, Davis LH (1987) Large proportion of marine planktonic ciliates found to contain functional chloroplasts. Nature 326:790-792

Stoecker DK, Gallager SM, Langdon CJ, Davis LH (1995) Particle capture by Favella sp. (Ciliata, Tintinnina). J Plankton Res 17:1105-1124

Tamar H (1979) The movements of jumping ciliates. Arch Protistenkd 122:290-327

Taniguchi A, Takeda Y (1988) Feeding rate and behavior of the tintinnid ciliate Favella taraikaensis observed with a high speed VTR system. Mar Microb Food Webs 3:21-34

Taylor WD (1978) Maximum growth rate, size and commonness in a community of bactivorous ciliates. Oecologia 36: 263-272

Taylor WD, Heynen ML (1987) Seasonal and vertical distribution of Ciliophora in Lake Ontario. Can J Fish Aquat Sci 44:2185-2191

Vaqué D, Blough HA, Duarte CM (1997) Dynamics of ciliate abundance, biomass and community composition in an oligotrophic coastal environment (NW Mediterranean). Aquat Microb Ecol 12:71-83

Verity PG (1991) Measurement and simulation of prey uptake by marine planktonic ciliates fed plastidic and aplastidic nanoplankton. Limnol Oceanogr 36:729-750

Verity PG, Stoecker DK, Sieracki ME, Nelson JR (1993) Grazing, growth and mortality of microzooplankton during the 1989 North Atlantic spring bloom at $47^{\circ} \mathrm{N}, 18^{\circ} \mathrm{W}$. DeepSea Res 40:1793-1814

Weisse T (1993) Dynamics of autotrophic picoplankton in marine and freshwater ecosystems. Adv Microb Ecol 13: $327-370$

Weisse T, Müller H, Pinto Coelho RM, Schweizer A, Springmann D, Baldringer G (1990) Response of the microbial loop to the phytoplankton spring bloom in a large prealpine lake. Limnol Oceanogr 35:781-794

Zubkov MV, Sleigh MA (1996) Bacterivory by the ciliate Euplotes in different states of hunger. FEMS Microbiol Ecol 20:137-147

Submitted: November 22, 1999; Accepted: May 3, 2000

Proofs received from author(s): May 29, 2000 